Çukurova Üniversitesi Mühendislik Fakültesi Dergisi, 36(4), ss. 869-878, Aralık 2021

Cukurova University Journal of the Faculty of Engineering, 36(4), pp. 869-878, December 2021

\title{
Investigation of Sediment Deposition in Dam Reservoirs
}

\section{Şerife Pınar GÜVEL ${ }^{* 1}$ ORCID 0000-0002-3175-5938}

\author{
${ }^{1}$ General Directorate of State Hydraulic Works, $6^{\text {th }}$ Regional Directorate, Adana
}

Geliş tarihi: 26.07.2021 Kabul tarihi: 10.12.2021

Atıf şekli/ How to cite: GÜVEL, Ş.P., (2021). Investigation of Sediment Deposition in Dam Reservoirs. Çukurova Üniversitesi, Mühendislik Fakültesi Dergisi, 36(4), 869-878.

\begin{abstract}
The goal of this study is to investigate the water storage capacity changes in Geographic Information System (GIS) environment due to sedimentation in Kozan Dam Reservoir by examining the local map of the reservoir area and the bathymetric measurements in 2014 of the reservoir. Kozan Dam is operational since 1972 and is located in Lower Ceyhan River Basin in Turkey. Reservoir storage capacity loss is estimated by using GIS tools in digital environment and found as \%88.7, \%7.5 and \%6.5 at minimum, normal and maximum operation level of the reservoir respectively. The need for rehabilitation has arisen in Kozan Irrigation Project in time. In terms of efficient use of water, it is necessary to monitor the amount of water stored in Kozan Dam Reservoir which is used as a water resource of the irrigation project in terms of providing expected performance.
\end{abstract}

Keywords: Reservoir sedimentation, Bathymetry, Water resources management

\section{Baraj Rezervuarlarında Sediment Birikiminin İncelenmesi}

\section{$\ddot{\mathbf{O z}}$}

Bu çalışmanın amacı, Kozan Baraj rezervuarında, rezervuar alanının yerel haritası ve 2014 yılı batimetri ölçümlerini kullanarak, katı madde birikiminden kaynaklanan rezervuar depolama kapasitesi değişimini Coğrafi Bilgi Sistemi (CBS) ortamında araştırmaktır. Kozan Barajı 1972'den beri işletme aşamasındadır ve Türkiye'de Aşağı Ceyhan Nehir Havzasında yer almaktadır. Rezervuar depolama kapasitesi kaybı, sayısal ortamda CBS araçları kullanılarak tahmin edilmiş ve rezervuarın minimum, normal ve maksimum işletme seviyelerinde sırasıyla \%88,7, \%7,5 ve \%6,5 olarak bulunmuştur. Kozan Sulama Projesinde zamanla rehabilitasyon ihtiyacı ortaya çıkmıştır. Suyun verimli kullanılması ve beklenen performansın sağlanması açısından, sulama projesinin su kaynağı olarak kullanılan Kozan Barajı'nda depolanan su miktarının izlenmesi gerekmektedir.

Anahtar Kelimeler: Rezervuarda sediment birikimi, Batimetri, Su kaynakları yönetimi

*Sorumlu yazar (Corresponding author): Şerife Pınar GÜVEL, spinar.guvel@dsi.gov.tr 


\section{INTRODUCTION}

Bathymetric surveys are conducted to detect changes in bottom topography of oceans, reservoirs, lakes, rivers and coastal areas [1-7]. The accuracy of underwater topography measurements is important for constructing harbour and coastal structures, transportation in rivers and evaluation of monitoring activities in reservoirs and lakes. Bathymetric maps are prepared by making measurements depending on the depth in order to determine the underwater topography. There are various methods that are used in bathymetry survey such as classical methods, acoustic sonar measurement methods [8], satellite-derived remote sensing techniques [9-13], survey techniques using unmanned aerial vehicles [14] and unmanned surface vehicles [15]. Nowadays, traditional methods are replaced by easy to use, labour and cost saving methods using advanced devices.

The quantity and quality of water resources are important in terms of benefiting from water resources for various purposes such as irrigation, energy, water supply, or flood control. Meteorological, environmental and human impacts in the scope of the effects on water management strategies are examined in the search of solutions to the problems caused. In this context, the changes of the water volume stored in reservoirs of dams that are constructed on rivers are regularly monitored. In the literature, it is seen that GIS is used in many research studies on the issues such as irrigation [16-17], flood analysis [18-19], water quality [20], groundwater [21-22], environmental management, monitoring and evaluation works of water-related parameters. In recent years, research studies on one or more of the issues on reservoir bathymetry survey methods, sediment transport, sediment yield and reservoir sedimentation have been seen in the literature [8,23-36]. Dadoria and Tiwari (2016) presented a review study in the field of sedimentation based on review of detailed study of various researchers [37]. Adongo et al. (2019) generated bathymetric TIN maps of 9 reservoirs in Ghana interpolating depth points by using GIS tools for investigating reservoir sedimentation [38]. Darama et al. (2019) analysed bathymetric data of Hasanlar Dam Reservoir in GIS environment with the aim of investigation of reservoir sedimentation [39]. Güvel and Yurtal (2020) investigated the changes in sediment accumulation in Seyhan Dam Reservoir by using historical hydrographic measurements [40].

In this study, it is aimed to investigate the effects of sedimentation in Kozan Dam Reservoir on water resources management studies by using bathymetric-based data of the year 2014 in comparison with local topography map of the reservoir area before the dam constructed.

\section{STUDY AREA}

Kozan Dam reservoir area is selected as the study area to investigate sediment threat on Kozan Dam reservoir and sedimentation effects on operation works of the dam. Kozan Dam was constructed in the north of Kozan in Adana in the Lower Ceyhan River Basin. The main stream branch of the dam is Kilgen River and its tributary branches are Kirksuyu Stream and Dalacak Stream. Kozan Dam characteristics are given in Table 1 and the location of Kozan Dam is shown in Figure 1.

Table 1. Kozan Dam characteristics

\begin{tabular}{|l|l|}
\hline Characteristics & Data \\
\hline River Basin & Ceyhan \\
\hline River & Kilgen \\
\hline Type & Rock fill \\
\hline Date put into operation & 1972 \\
\hline Purpose & Irrigation \\
\hline
\end{tabular}




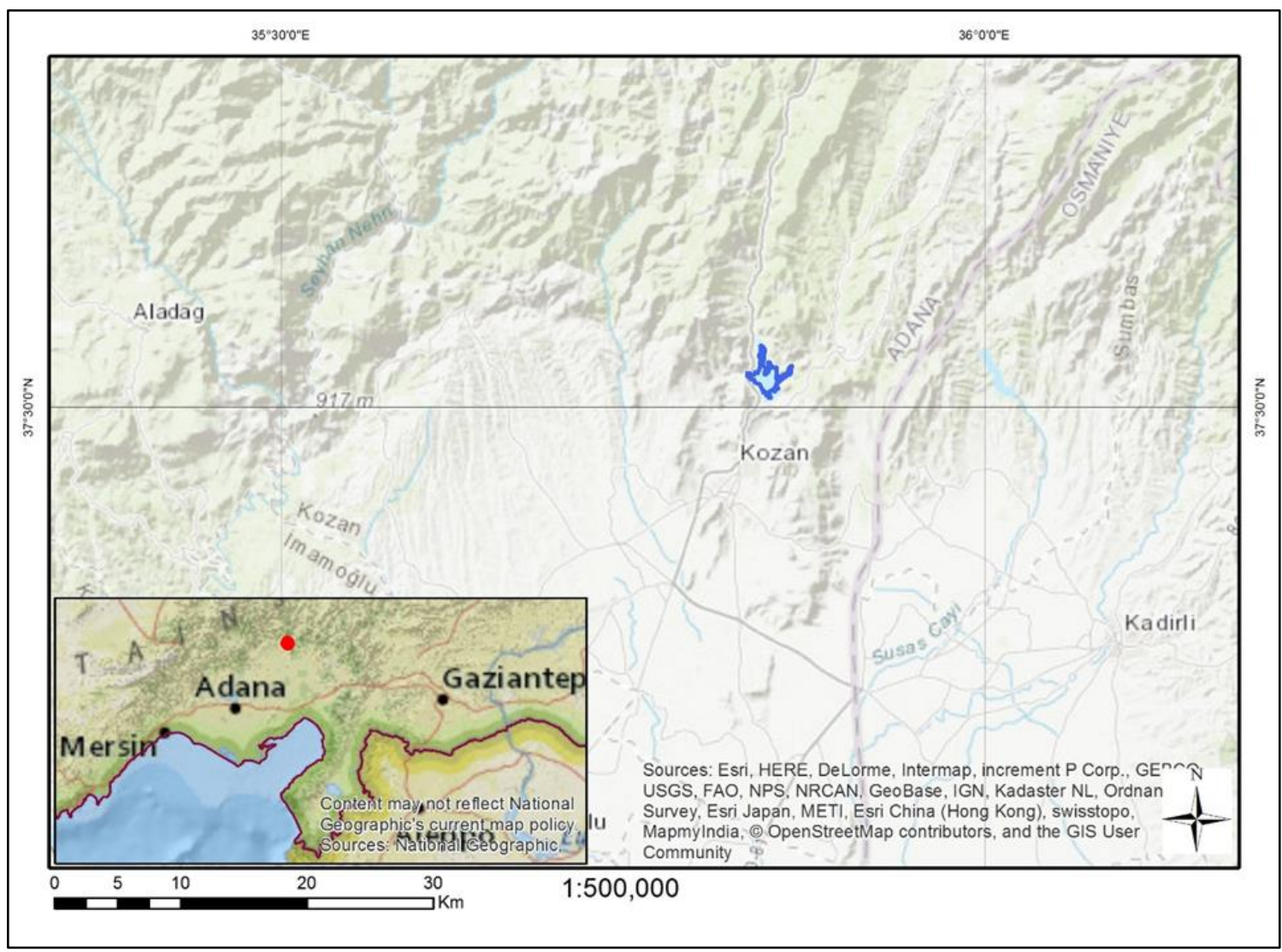

Figure 1. The location of Kozan Dam in Turkey

\section{MATERIAL AND METHOD}

The topographic maps of the Kozan Dam reservoir area prepared in 1962 and the bathymetric map of Kozan Dam reservoir prepared in 2014 were obtained from DSI archive. The topographic maps were created by using aero photogrammetry method. In order to digitize the maps obtaining the reservoir area topography prepared in 1962, the maps have been scanned and transferred into GIS environment with referenced coordinates, the elevation information on the maps has been added to attribute table with integrating location information. Digitized map of the reservoir area before the construction of Kozan Dam is given in Figure 2(a). Survey data of bathymetric measurements of Kozan Dam reservoir in 2014 was carried out by photogrammetric method on the land side and by using echo-sounder on the water side, the hydrographic map of the reservoir was produced integrating both land side data and water side data. Depth and location information of bathymetric survey is integrated in the database using tools of required software in preparing of hydrographic maps, measured values can be extracted to CAD/GIS software to create 3D models and to assess outputs of geographic analysis. Bathymetric map of 2014 in NCZ format in GIS environment is given in Figure 2(b). In this study, ArcGIS software was used to create and evaluate digital models of the reservoir. Analysis of the topography map versus the bathymetric map, and creating digital surfaces were carried out by using GIS. ArcGIS software was used to create 3D models of Kozan Dam reservoir and sediment thickness map of the reservoir. 


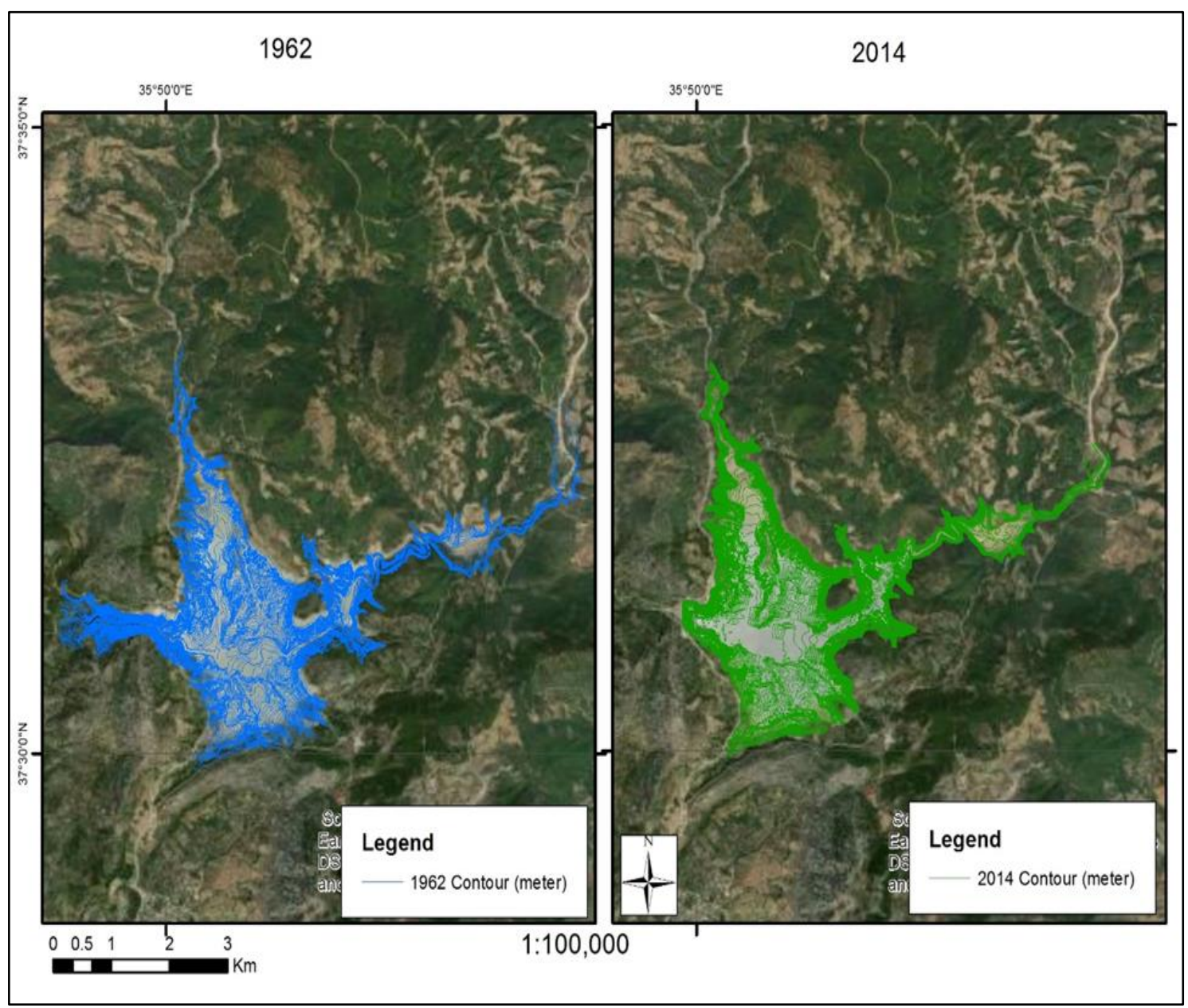

Figure 2. (a) The digitized map of the reservoir area before the construction of Kozan Dam, (b) The image of Kozan Dam reservoir bathymetric survey data of 2014

\section{RESULTS AND DISCUSSION}

The map of 1962 of the dam site and the reservoir area was digitized by using ArcGIS; TIN (Triangular Irregulated Network) interpolation method was used to create digital model of the dam site and the reservoir area before dam construction which is shown in Figure 3 (a). Reservoir bathymetric survey data of 2014 was used to create 3D model of Kozan Dam reservoir of 2014 which is shown in Figure 3(b). Reservoir storage capacity at certain water levels were calculated based on both two 3D models by using GIS tools. Volume-elevation chart for two models were prepared to compare the water volumes at certain levels. The capacity loss between years provides the information about sedimentation amount.

Volume-elevation curve of the Kozan Dam reservoir is seen in Figure 4. Reservoir storage capacity loss of the Kozan Dam reservoir at minimum, normal and maximum operation level of the reservoir is estimated as \%88,7, \%7,5 and $\% 6,5$ respectively by using GIS analysis tools. 


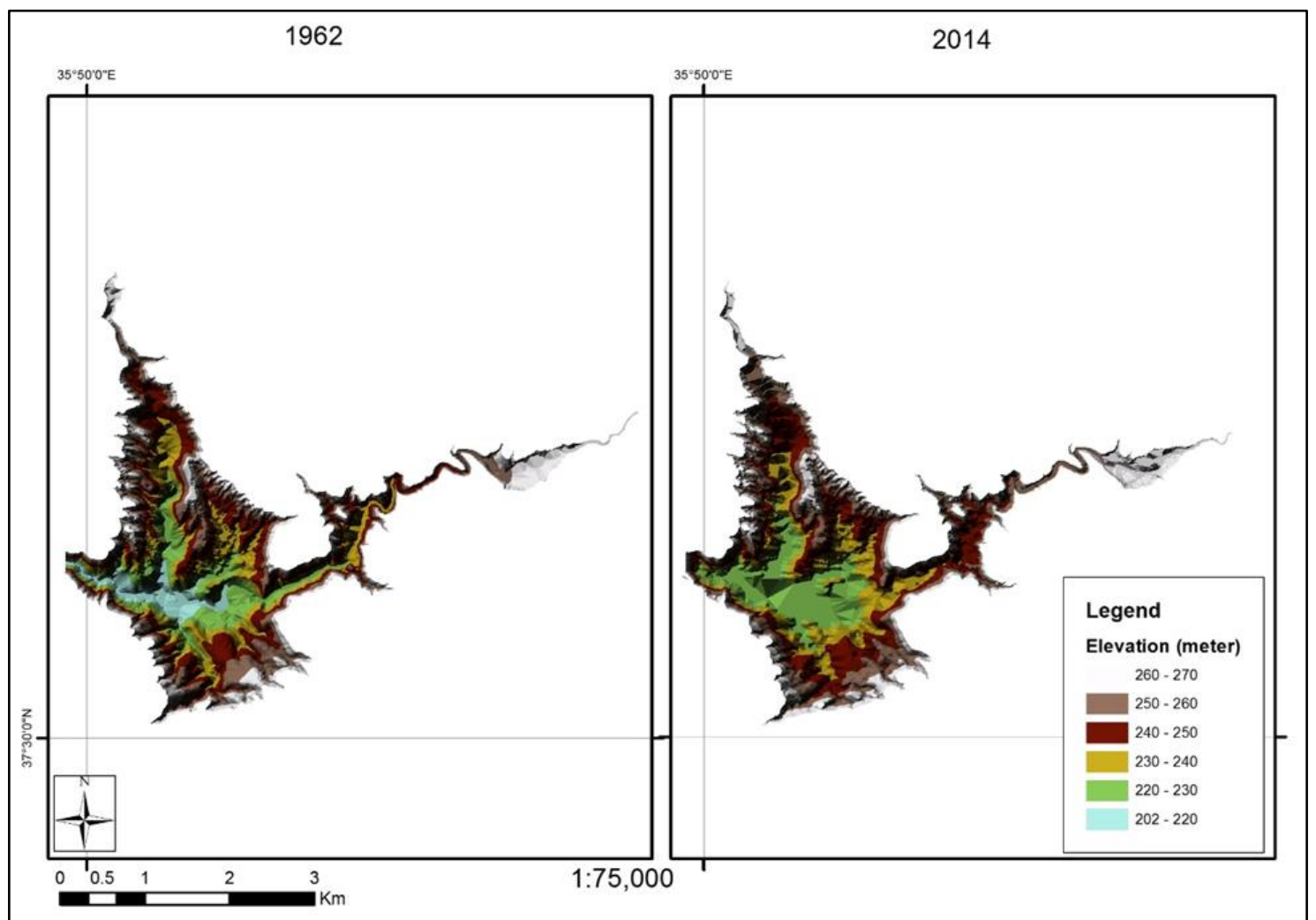

Figure 3. (a) 3D model of the reservoir area before the construction of Kozan Dam in 1962, (b) 3D model of Kozan Dam reservoir in 2014

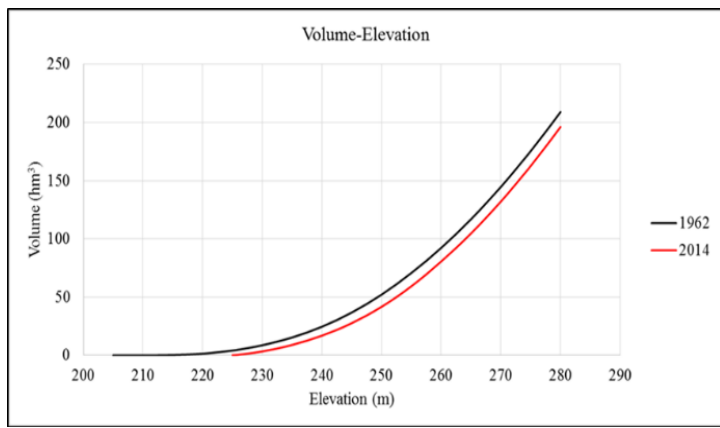

Figure 4. Volume-elevation curve of the Kozan Dam reservoir

The sub-basin area of Kirksuyu Stream is approximately 4.8 times larger than the area of the sub-basin of Dalacak Stream, therefore it has been evaluated that the main source of sediment coming to Kozan dam reservoir is Kurksuyu Stream subbasin.
Sediment thickness map of Kozan Dam Reservoir was obtained by comparing the dimensional models of 1962 and 2014 in GIS environment (Figure 5). The sediment thickness in front of the dam body in the reservoir area is up to 18 meters. The storage volume loss of $\% 88.7$ in dead volume capacity; the analysis and calculation of the revised storage volume of the reservoir compared to the previous condition indicates the necessity of the revision on operation-maintenance works depending on not only water volume changes but also the possibility of usability of water intake structure of the dam body.

As seen in Figure 5, the bottom elevation of the reservoir has been assessed to be decreased due to erosion underwater on the left side of the dam reservoir close to thalweg. Sediment accumulation between $0-5 \mathrm{~m}$ and underwater erosion between $-5-0 \mathrm{~m}$ are seen in the central parts of the reservoir 
by examining the sediment thickness map between 2014 and 1962. It is seen that in the upstream erosion occurred along the shoreline and there is sediment accumulation in the middle parts.
Sediment accumulation in the area close to the dam body has rised up to 15 meters by 2014 . There is no available data on erosion in the reservoir.

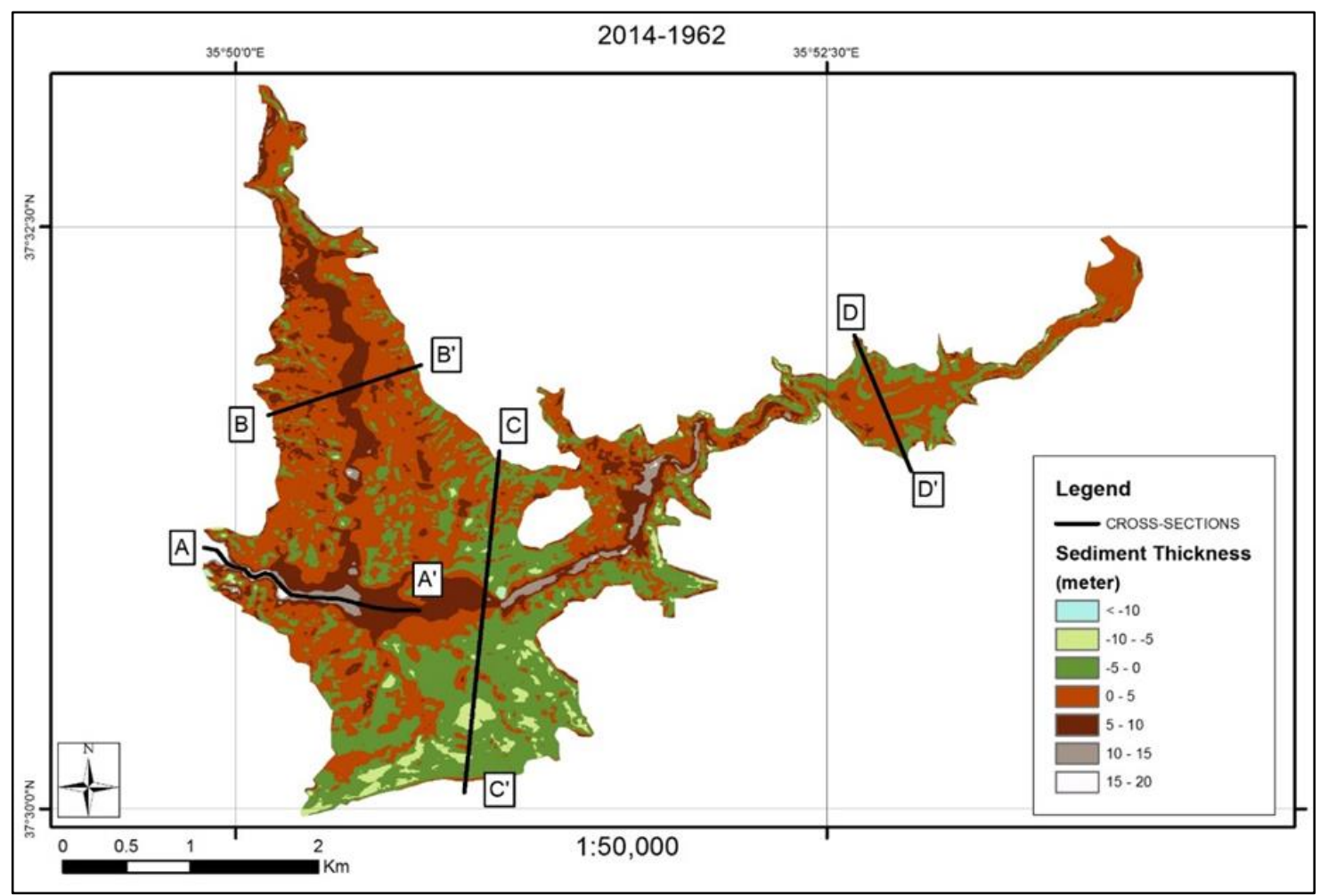

Figure 5. Sediment thickness map of Kozan Dam Reservoir between 2014 and 1962

The cross-sections in the reservoir shows the sediment accumulation and the elevation changes between 2014 and 1962 (Figure 6). It is seen that minimum ground topography elevation in front of the dam body is 224 meters in 2014 as seen in the cross-section A-A' in Figure 6.a, so the operation works of the dam has to be revised upon revised volume-elevation-area chart. The cross-section BB' shows the elevation changes caused by transported sediment from sub-basin of Dalacak Stream which is the tributary of Kilgen River. Sediment accumulation in B-B' cross-section (Figure 6.b) is between 0-10 meters. Erosion effect on the shoreline of the reservoir is seen at the cross-section C-C' (Figure 6.c), there's no available historical data records about the main causes of erosion on this side. Sediment accumulation is also seen on this cross-section. The cross-section D-D' (Figure 6.d) shows the elevation changes caused by coastal erosion in the upstream.

Irrigation rehabilitation studies are carried out in order to use water efficiently in cases where the amount of water required for irrigation is insufficient in irrigation projects or inadequate efficiency from irrigation facilities. Kozan Dam reservoir is the water resource of Kozan Irrigation Project. The storage volume capacity of Kozan Dam Reservoir and sedimentation impacts on the dam body and the reservoir have to be monitored regularly because of its effect on the operation works of the irrigation project. 


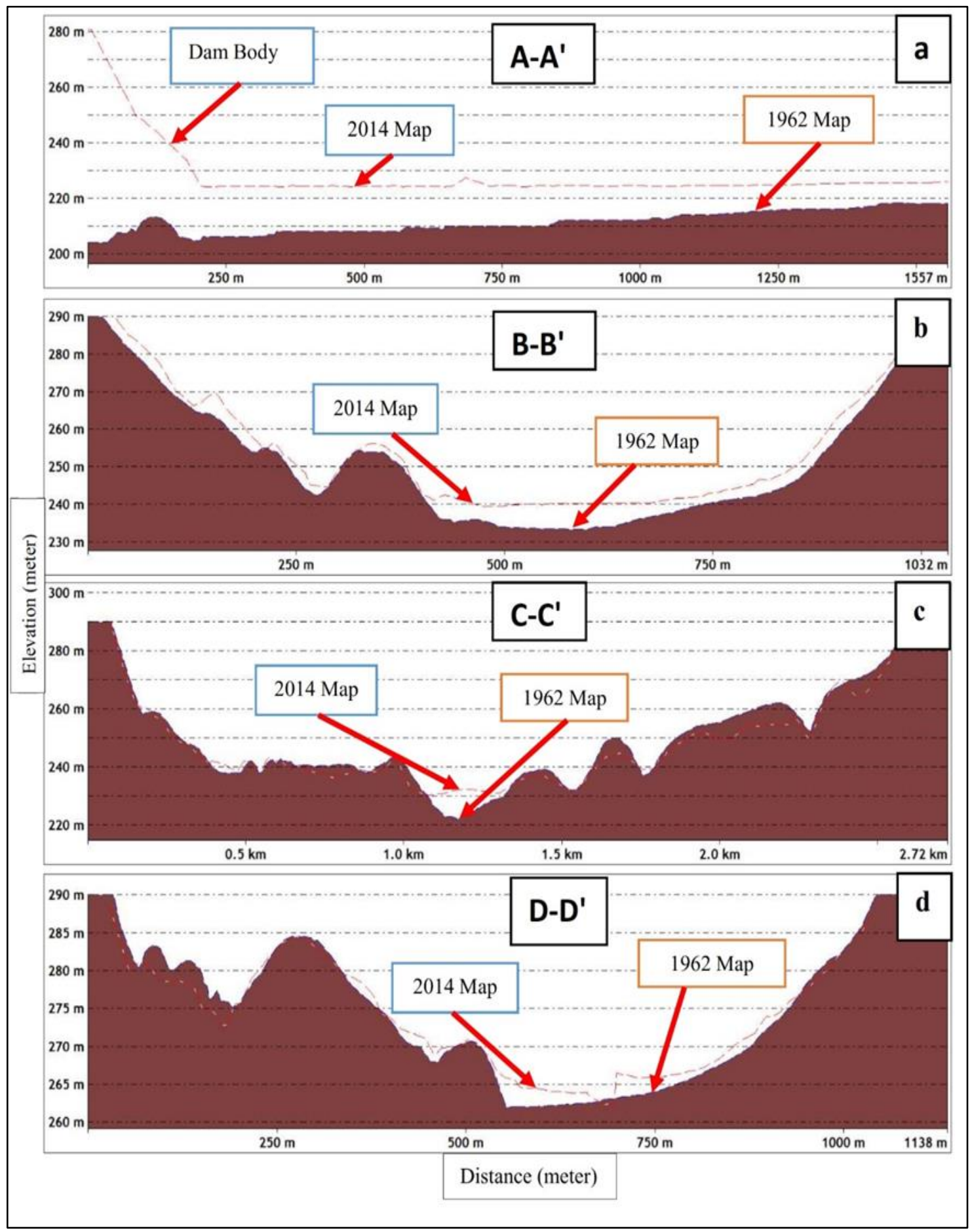

Figure 6. The sediment accumulation on sample cross sections in Kozan Dam Reservoir between 2014 and 1962 


\section{CONCLUSION}

Bathymetric surveys are carried out to map details of ground topography in lakes, reservoirs and oceans; integrated hardware and software technology with high capacity is essential to provide high resolution bathymetry data. The areal sizes of reservoirs, climate factors and topography of coastline of reservoirs are needed to be taken into account in determining period and cost of bathymetric surveys.

Sediment thickness map of Kozan Dam Reservoir was prepared in GIS environment, then spatial and temporal changes of sediment accumulation up to 2014 in Kozan Dam Reservoir was estimated.

Reservoir storage capacity is calculated by using 3D models in GIS environment and storage capacity loss is estimated as \%88.7, \%7.5 and $\% 6.5$ at minimum, normal and maximum operation level of the reservoir respectively.

The analysis results of this study obtained by using GIS tools will contribute future works on investigation of sedimentation impacts on operation works of the dam. The results will also contribute next researches based on new bathymetric survey data in the future.

\section{REFERENCES}

1. Cross, B.K., Moore, B.C., 2014. Lake and Reservoir Volume: Hydroacoustic Survey Resolution and Accuracy. Lake and Reservoir Management, 30(4), 405-411. DOI: 10.1080/10402381.2014.960115.

2. Popielarczyk, D., Templin, T., 2014. Application of Integrated GNSS/Hydroacoustic Measurements and GIS Geodatabase Models for Bottom Analysis of Lake Hancza: the Deepest Inland Reservoir in Poland. Pure Appl. Geophys, 171, 997-1011.

3. Borowiak, D., Nowiński, K., Grabowska, K., 2016. A New Bathymetric Survey of the Suwałki Landscape Park Lakes, Limnol. Rev. 16(4), 185-197.
4. Olushola, S.O., Ehigiator-Irughe, R., 2017. Bathymetric and Volumetric Analysis of Jebba (Hydropower) Dam Harnessing its Capability for Multipurpose Use. Nigerian Journal of Environmental Sciences and Technology (NIJEST), 1(1), 111-122.

5. Maxim, A., Adrian, R., Alina-Florina, N., Lucian, G.P., Daniel-Eduard, C., 2017. Comparison of Models and Volumetric Determination for Catusa Lake, Galati. TEHNOMUS-New Technologies and Products in Machine Manufacturing Technologies, 67-71.

6. Muchanga, M., Sichingabula, H.M., Obando, J., Chomba, I., Sikazwe, H., Chisola, M., 2019. Bathymetry of the Makoye Reservoir and its Implications on Water Security for Livestock Within the Catchment. International Journal of Geography and Geology, 8(3), 93-109.

7. Parente, C., Vallario, A., 2019. Interpolation of Single Beam Echo Sounder Data for 3D Bathymetric Model. (IJACSA) International Journal of Advanced Computer Science and Applications, 10(10), 6-13.

8. Stoleriu, C.C., Romanescu, G., Mihu-Pintilie, A., 2019. Using Single-beam Echo-sounder for Assessing the Silting Rate from the Largest Cross-border Reservoir of the Eastern Europe: Stanca-costesti Lake, Romania and Republic of Moldova. Carpathian Journal of Earth and Environmental Sciences, February 2019, 14(1), 83-94.

9. Jagalingam, P., Akshaya, B.J., Hegde, A.V., 2015. Bathymetry Mapping Using Landsat 8 Satellite Imagery. $8^{\text {th }}$ International Conference on Asian and Pacific Coasts (APAC 2015). Procedia Engineering, 116, 560-566.

10. Manessa, M.D.M., Haidar, M., Hastuti, M., Kresnawati, D.K., 2017. Determination of the Best Methodology for Bathymetry Mapping Using Spot 6 Imagery: A Study of 12 Empirical Algorithms. International Journal of Remote Sensing and Earth Sciences, 14(2), 127-136.

11. Pushparaj, J., Hegde, A.V., 2017. Estimation of Bathymetry Along the Coast of Mangaluru using Landsat- 8 Imagery. The International Journal of Ocean and Climate Systems, 8(2), 71-83. 
12. Akgül, M.A., Dağdeviren, M., Biroğlu, İ., 2018. Satellite-derived Bathymetry Using Multi-temporal Satellite Images. DSI Technical Bulletin, 127, 14-27 (in Turkish).

13. Duplančić Leder, T., Leder, N., 2020. Optimal Conditions for Satellite Derived Bathymetry (SDB) Case Study of the Adriatic Sea. FIG Working Week 2020, Smart Surveyors for Land and Water Management, Amsterdam, the Netherlands, 10-14 May 2020.

14. Rossi, L., Mammi, I., Pelliccia, F., 2020. UAVDerived Multispectral Bathymetry. Remote Sensing, 12(23), 3897; doi:10.3390/ rs12233897.

15. Suhari, K. T., Karim, H., Gunawan, P. H., and Purwanto, H., 2017. Small ROV Marine Boat for Bathymetry Surveys of Shallow WatersPotential Implementation in Malaysia. Int. Arch. Photogramm. Remote Sens. Spatial Inf. Sci., XLII-4/W5, 201-208, https://doi.org/ 10.5194/isprs-archives-XLII-4-W5-201-2017, 2017.

16. Acharya, S., Pandey, A., Mishra, S.K., Chaube, U.C., 2016. GIS Based Graphical User Interface for Irrigation Management. Water Science \& Technology: Water Supply, 16(6), 1536-1551.

17. Negi, S., Arya, A., Kathota, J.C., Patel, A.N., Singh, V., Garg, J.K., Kalubarme, M.H., 2019. Analysis of Impact of Canal Irrigation on Waterlogged Areas and Environment Using Geo-informatics Technology in Gujarat State, INDIA, International Journal of Environment and Geoinformatics (IJEGEO), 6(2), 172-185. DOI: $10.30897 /$ ijegeo.541714.

18. Akinbobola, A., Okogbue, E.C., Olajire, O.O., 2015. A GIS-based Flood Risk Mapping Along The Niger-Benue River Basin in Nigeria Using Watershed Approach. Ethiopian Journal of Environmental Studies \& Management, 8(6), 616-627.

19. Dang, A.T.N., Kumar, L., 2017. Application of Remote Sensing and GIS-based Hydrological Modelling for Flood Risk Analysis: a Case Study of District 8, Ho Chi Minh City, Vietnam. Geomatics, Natural Hazards and Risk, $\quad 8(2), \quad 1792-1811, \quad$ DOI: 10.1080/19475705.2017.1388853.
20. Akgül, M.A., Dağdeviren, M., Ekmekçi, F., Kağnıcioğlu, N., 2019. Estimation of Water Quality Parameters in Lake Köyceğiz Using Remote Sensing. 10. Ulusal Hidroloji Kongresi, 9-12 Ekim 2019 (in Turkish).

21. Augusto Filho, O., Soares, W., Fernandéz, C.I., 2016. Mapping of the Water Table Levels of Unconfined Aquifers Using Two Interpolation Methods. Journal of Geographic Information System, 8, 480-494.

22. Kisaka, M., Mato, R., 2018. Spatial Variation of Ground water Quality Parameters and its Suitability for Drinking at Makutopora Aquifer, Dodoma Municipality, Tanzania. International Journal of Environment and Geoinformatics (IJEGEO). 5(3):337-.352. DOI: 10.30897/ijegeo.462691.

23. Jolly, J.P., 1982. A Proposed Method for Accurately Calculating Sediment Yields from Reservoir Deposition Volumes, Recent Developments in the Explanation and Prediction of Erosion and Sediment Yield (Proceedings of the Exeter Symposium, July 1982), IAHS Publ.no.137.

24. White, W.R., 1990. Reservoir Sedimentation and Flushing. Hydrology in Mountainous Regions, II-Artificial Reservoirs; Water and Slopes (Proceedings of two Lausanne Symposia, August 1990). IAHS Publ. 194, 129-139.

25. Taruya, H., Fuji, H., 1997. Current Conditions of Reservoir Sedimentation in Irrigation Dams in Japan. JARQ, 31(1), 29-34.

26. Magnuszewski, A., Moran, S., Yu, G., 2010. Modelling Lowland Reservoir Sedimentation Conditions and the Potential Environmental Consequences of Dam Removal: Wloclawek Reservoir, Vistula River, Poland, Sediment Dynamics for a Changing Future (Proceedings of the ICCE Symposium Held at Warsaw University of Life Sciences-SGGW, Poland, 14-18 June 2010). IAHS Publ. 337.

27. Munthali, K.G., Irvine, B.J., Murayama, Y. 2011. Reservoir Sedimentation and Flood Control: Using a Geographical Information System to Estimate Sediment Yield of the Songwe River Watershed in Malawi. Sustainability 2011, 3(1), 254-269; doi:10.3390/su3010254. 
28. Onwuegbunam, D.O., M.A. Oyebode, Onwuegbunam N.E., Maikano S., Waziri C.H., 2013. Sedimentation Assessment of a Small Reservoir at Afaka Forest Reserve, Kaduna, Nigeria. Journal of Environment and Earth Science, ISSN 2224-3216 (Paper) ISSN 2225 0948 (Online), 3(9) 183-190.

29. Schleiss, A.J., Franca, M.J., Juez, C., De Cesare, G., 2016. Reservoir Sedimentation. Journal of Hydraulic Research, 54(6), 595-614. DOI: 10.1080/00221686.2016.1225320.

30. Shendge, R.B., Chockalingam, M.P., 2016. Review of Reservoir Sedimentation, Remote Sensing and GIS Technology. International Journal of Innovations in Engineering Research and Technology (IJIERT), 3(6), 45-51.

31. Jansen, L., Sidek, L.M., Jajarmizadeh, M., 2016. Impact of Sedimentation Hazard at Jor Reservoir, Batang Padang Hydroelectric Scheme in Malaysia. International Conference on Advances in Renewable Energy and Technologies (ICARET2016), IOP Conf. Series: Earth and Environmental Science, 32, 012030.

32. Maloi, S.K., Sang, J.K., Raude, J.M., Mutwiwa, U.N., Mati, B.M., Maina, C.W., 2016. Assessment of Sedimentation Status of Ruiru Reservoir, Central Kenya, American Journal of Water Resources, 4(4), 77-82. doi: 10.12691/ajwr-4-4-1.

33. Obialor, C.A., Okeke, O.C., Onunkwo, A.A., Fagorite, V.I., Ehujuo, N.N., 2019. Reservoir Sedimentation: Causes, Effects and Mitigation. International Journal of Advanced Academic Research, Sciences, Technology and Engineering, 5(10), 92-109.

34. Lucian, C.D., Mihu-Pintilie, A., Elena, P.L., Stoleriu, C.C., 2019. 50 Year's Determination of Reservoir Sedimentation Rate Using Topography Measurements and GIS. Case Study: Strîmtori-Firiza Reservoir, Baia Mare, Romania. International Scientific Conference Geobalcanica 2019, 591-596, DOI: 10.18509/GBP.2019.69.

35. Výleta, R., Valent, P., Danáčová, Z., 2020. Monitoring Changes in the Morphology and Storage of a Small Water Reservoir: A Case Study from Vrbovce, Slovakia. Slovak Journal of Civil Engineering, 28(2), 30-35.
36. Uzor-Totty, A.E., Oyegun, C.U., 2020. Spatiotemporal Dynamics of Sediment Yield Across the Imo River Basin SE Nigeria. International Journal of Environment and Geoinformatics (IJEGEO), 7(2), 184-190. DOI: 10.30897/ijegeo.645611.

37. Dadoria, D., Tiwari, H.L., 2016. Assessment of Sedimentation by GIS-A Review. International Journal of Engineering and Technical Research (IJETR), ISSN: 2321-0869 (O) 2454-4698 (P), 5(3), 124-128.

38. Adongo, T.A., Kyei-Baffour, N., Abagale, F.K., Agyare, W.A., 2019. Assessment of Reservoir Sedimentation of Irrigation Dams in Northern Ghana. Lake and Reservoir Management, 36, 87-105. DOI: 10.1080/10402381.2019.1659461

39. Darama, Y., Selek, Z., Selek, B., Akgül, M.A., Dağdeviren, M., 2019. Determination of Sediment Deposition of Hasanlar Dam Using Bathymetric and Remote Sensing Studies. Natural Hazards, 97, 211-227, DOI: 10.1007/s11069-019-03635-y.

40. Güvel, Ş.P., Yurtal, R., 2020. Investigation of Sedimentation Effects on Seyhan Dam Reservoir, Journal of the Faculty of Engineering and Architecture of Gazi University 35(2) 1015-1025. 